\title{
Apolipoprotein E polymorphism as a predictor for cognitive decline and dementia in the Saudi general population over 65 years
}

\author{
Abdulaziz Ali A. Al-Khedhairy \\ Department of Zoology, College of Sciences, King Saud University, Riyadh, Saudi Arabia.
}

\begin{abstract}
Specific Apolipoprotein E (ApoE) genotypes are thought to be associated with risk for Alzheimer's disease (AD). It is essential to understand how this genetic factor affects cognitive decline and dementia in the general population. One hundred and fifty elderly persons residing at social nursing centers in different provinces of Saudi Arabia were tested for ApoE genotypes, using PCR amplification of genomic DNA followed by DNA digestion with Cfo I. All subjects were diagnosed with regard to cognitive decline and dementia. In the general Saudi population, the ApoE4 allele was found to be a weaker predictor for dementia than for AD. This may be a result of non-AD pathological processes and/or of most prevalent dementia at an age when the ApoE4 effect on the AD/dementia risk has decreased.
\end{abstract}

Key words: ApoE, Alzheimer's disease, dementia, Saudi population.

Received: October 10, 2003; Accepted: April 26, 2004.

\section{Introduction}

The Apolipoprotein E (ApoE) gene on chromosome 19 has been linked to the development of Alzheimer's disease (AD). The role of apolipoprotein $E$ alleles and isoforms in the etiology and pathogenesis of $\mathrm{AD}$ has been discussed by various workers (Chartier-Harlin et al., 1994; Egensperger et al., 1995; Hardy, 1995; Lippa et al., 1995; Lambert et al., 1997). The ApoE4 allele is a risk factor for the development of familial (Corder et al., 1993; Houlden et al., 1993) and sporadic (Saunders et al., 1993; Van Duijin et al., 1995) AD. It accounts for $\sim 45-60 \%$ of all cases (Farrer et al., 1997).

The $\mathrm{E}_{4}$ allele is associated with an increased risk factor of AD in an allele dose- dependant manner (Strittmatter et al., 1993; Corder et al., 1993). It appears to modulate the age of onset also in a dose-dependent fashion. One and two $\mathrm{E}_{4}$ alleles may lower the age of onset by up to 5 and 10 years, respectively (Houlden et al., 1994). The ApoE4 allele associates with an increased frequency of $\beta$-amyloid in individuals with late AD (Schmechel et al., 1993). It has also been associated with a risk for carotid atherosclerosis, diabetic neuropathy, diabetis mellitus and some severe liver diseases and cardiovascular disease (CVD) (Cattin et al., 1997; Lahoz et al., 2001; Eto et al., 2002; Kalina et al., 2002; Wozniak et al., 2002).

Send correspondence to Abdulaziz Ali A. Al-Khedhairy. King Saud University, College of Sciences, Department of Zoology, P.O. Box 2455, Riyadh 11451, Saudi Arabia, E- mail: kedhairy @ ksu.edu.sa.
Based on the author's experience at medical and social centers maintained by the Ministry of Labor and Social Welfare of Saudi Arabia, this paper aimed to implement the idea of genetic factors as predictors for cognitive decline and dementia. In this study, the elderly population of Saudi Arabia was tested for ApoE genotypes and a possible link with cognitive decline and dementia.

\section{Material and Methods}

One hundred and fifty elderly Saudi individuals of ages varying from 68 to 95 years (mean: $75 \pm 5$ years) residing at social nursing centers in three provinces of Saudi Arabia were involved in the study. The various nursing centers were located in Dammam (eastern province), Riyadh (central province) and Makkah (western province). The subjects were diagnosed with or without cognitive decline and dementia, based on the differences in their mini-mental scale examination (MMSE) scores between the first and second assessment waves (about three years apart) and clinical dementia rating (CDR) scores established by a clinical psychiatrist. The subjects with and without dementia belonged almost to the same age group. The subjects with dementia had severe memory and behavioral problems and were completely bedridden. These patients underwent complete neurological and medical examination. They were diagnosed to have senile dementia. However, they were not further classified as having AD or other types of dementia. 
DNA was extracted from blood by standard procedures utilizing the GFX Genomic Blood DNA purification Kit (Amersham, USA). Primers were designed to amplify the coding sequence of ApoE. PCR was performed using PuRe Taq Ready-To-Go PCR Beads (Amersham, USA) with the following primers:

Forward primer: 5' -gac gcg ggc acg gct gtc caa gga gct gca ggc gac gca ggc ccg get gga cgc gga cat gga gga-3'

Reverse primer: 5'-agg cca cgc tcg acg ccc tcg cgg gcc ccg gcc tgg tac act-3'

A sample of 200-300 ng of genomic DNA was used as a template in $25 \mu \mathrm{L}$ reaction solution. Genomic DNA was amplified for 40 cycles. Each cycle consisted of $30 \mathrm{~s}$ at $94{ }^{\circ} \mathrm{C}, 10 \mathrm{~s}$ at $68^{\circ} \mathrm{C}$, and $1 \mathrm{~min}$ at $72^{\circ} \mathrm{C}$. The PCR products obtained were separated by electrophoresis on $1.5 \%$ agarose gel in TAE buffer, and visualized by ethidium bromide fluorescence. Fragments with the expected size were cut from the gel and purified using a GFX PCR DNA Gel band purification kit (Amersham, USA). The purified DNA was digested with $C f o 1$ enzyme to identify the ApoE genotypes and their frequency in individuals with and without dementia. Statistic analysis was performed using the chisquare test $\left(\chi^{2}\right.$-test).

\section{Results}

Upon digestion with $C f_{o} \mathrm{I}$, the PCR products revealed three genotypes: E3/E3, E3/E4, and E4/E4. The genotype frequencies in subjects with and without dementia are summarized in Table 1, and the allele frequencies are shown in Table 2. Genotype E3/E3 was the most prevalent (70.6\%) in the tested population, followed by E3/E4 (27.3\%); genotype E4/E4 was very rare (2.0\%). The differences in the prevalence of E3/E3 and E3/E4 in persons with and without dementia were nonsignificant (value of $p=0.2015$ ). Genotype E4/E4 was found only in 3 persons without dementia. Other genotypes with an E2 allele (E2 homozygotes as well as E2 heterozygotes) were absent in the tested population.

Statistical analysis of the data obtained for the prevalence of the various ApoE alleles among the elderly population of Saudi Arabia indicated that allele E3, with a frequency of $84 \%$, was more prevalent in the population under study, as compared to allele E4, whose frequency was $16 \%$. However, the frequency of E3 in people with and without dementia was 0.84328 and 0.84337 , respectively, a statistically nonsignificant difference (value of $\mathrm{p}=0.4991$ ).

Table 1 - ApoE genotype frequencies in elderly Saudi subjects with and without dementia.

\begin{tabular}{lcccccc}
\hline Genotype & $\begin{array}{c}\text { With } \\
\text { dementia }\end{array}$ & $\%$ & $\begin{array}{c}\text { Without } \\
\text { dementia }\end{array}$ & $\%$ & Total & $\%$ \\
\hline E3/E3 & 46 & 68.65 & 60 & 72.28 & 106 & 70.66 \\
E3/E4 & 21 & 31.34 & 20 & 24.09 & 41 & 27.33 \\
E4/E4 & 0 & 0 & 3 & 3.61 & 3 & 2 \\
Total & 67 & & 83 & & 150 & \\
\hline
\end{tabular}

Table 2 - ApoE allele frequencies in elderly Saudi subjects with and without dementia.

\begin{tabular}{lccccc}
\hline Allele & With dementia & $\%$ & Without dementia & $\%$ & Total \\
\hline E3 & 113 & 84.32 & 140 & 84.33 & 253 \\
E4 & 21 & 15.67 & 26 & 15.66 & 47 \\
Total & 134 & & 166 & & 300 \\
\hline
\end{tabular}

The difference between the frequencies of $\mathrm{E} 4$ in the population with and without dementia, 0.1567 and 0.1566 , respectively, was also nonsignificant, (value of $\mathrm{p}=0.50084$ ).

The present data indicate that the distribution of these alleles in subjects with and without dementia is similar. The subjects studied were from various centers located in three different provinces of the Kingdom of Saudi Arabia, with ethnical differences which allow them be considered as a representative sample of the country's general population.

\section{Discussion}

The frequency of the most common isoform ApoE3 was similar in subjects with and without dementia. Moreover, the frequency of allele E4 was not higher in the subjects with dementia, indicating that ApoE4 may not be associated with general dementia and cognitive decline in this population. Alternatively, the lower frequency or prevalence of allele E4 in the elderly Saudi population may be explained by an increased morbidity and mortality in middle-aged carriers of the ApoE4 allele, as reported elsewhere (Kalina et al., 2002) for elderly and diabetic subjects. If this is the case, then, similarly to other populations, ApoE4 may be a weak predictor of dementia and cognitive decline in the general Saudi population. Yip et al. (2002) studied the association between ApoE genotype and the dementia status in a community-based sample, the Medical Research Council Cognitive Function Aging Study (MRC CFAS), and suggested that the ApoE epsilon4 allele is a weaker predictor for dementia than for $\mathrm{AD}$ in the general population. Furthermore, there is a marked variation in whether people retain sufficient cognitive function in old age, as a consequence of dementia being caused by non-AD pathological processes, and most prevalent dementia occurs at an age when the apoE4 effect on $\mathrm{AD} /$ dementia risk has already declined. Similarly, in Germans living in the city of Zurich (Gostynski et al., 2002), possession of a single ApoE4 allele was not associated with high risk of developing dementia. Other studies also indicate that late-life dementia and quality of life in older age are independent of the ApoE4 allele, suggesting that there is no association with this allele (Butters et al., 2003; Blazer et al., 2003). Itoh and Yamada (1996) investigated the relation between the ApoE genotype and the density of senile plaques and number of neurofibrillary tangles in 69 elderly Japanese patients. Among these, 49 did not have dementia (age at death $=86.2 \pm 7.8$ years), although $7.1 \%$ of them carried the E4 allele. 
However, ApoE polymorphism has been associated worldwide with the risk of $\mathrm{AD}$, and ApoE4 is universally recognized as a major genetic risk factor for $\mathrm{AD}$ (ChartierHarlin et al., 1994; Egensperger et al., 1995; Hardy, 1995; Farrer et al., 1997; Lambert et al., 1997; Laws et al., 2002).

In the present study, subjects with dementia were not classified as having AD or other types of dementia. However, there was no association of the ApoE4 allele with dementia in the Saudis understudy. Furthermore, these elderly people were from centers located in three different provinces of Saudi Arabia with some ethnical differences. Makkah, the western province, represents the Saudi population living in Red Sea coastal regions with some migrants from Southeast Asia, while Riyadh, the central province, represents the original natives living in deserts. Dammam, the eastern province, has a mixed population of Saudis living in Arabian Gulf coastal regions. So, the subjects studied were considered as representative of the country's general population.

As shown by the literature, ApoE4 allele has been associated with AD worldwide (Chartier-Harlin et al., 1994; Egensperger et al., 1995; Hardy, 1995; Farrer et al., 1997; Lambert et al., 1997; Hu et al., 2000; Laws et al., 2002; Chalmers et al., 2003; Hawi et al., 2003; Nielsen et al., 2003). Therefore, it is speculated that, in the general Saudi population, allele ApoE4 may be a weaker predictor for dementia than for AD. This may be the result of non-AD pathological processes and/or of the fact that dementia is most prevalent at an age when the ApoE4 effect on $\mathrm{AD} / \mathrm{de}-$ mentia risk has decreased. However, further studies involving more subjects and factors are required to confirm this hypothesis.

\section{Acknowledgement}

The Author wishes to thank the Ministry of Labor and Social Welfare of the Kingdom of Saudi Arabia for the opportunity to work as a Medical Genetics Consultant.

\section{References}

Blazer DG, Fillenbaum GG, Gold DT, Burchett BM and Hays JC (2003) ApoE epsilon4 as a predictor of subjective quality of life in biracial older person community sample. J Aging Health 15(4):645-660.

Butters MA, Sweet RA, Mulsant BH, Ilyas Kamboh M, Pollock BG, Begley AE, Reynolds CF 3rd and DeKosky ST (2003) ApoE is associated with age of onset, but not cognitive functioning, in late-life depression. Int $\mathrm{J}$ Geriatr Psychiatry 18(12):1075-1081.

Cattin L, Fisicaro M, Tonizzo M, Valenti M, Danek GM, Fonda M, Da Col PG, Casagrande S, Pincetri E, Bovenzi M and Baralle F (1997) Polymorphism of the apolipoprotein E gene and early carotid atherosclerosis defined by ultrasonography in asymptomatic adults. Arterioscle Thromb Vasc Biol 1:91-94.

Chalmers K, Wilcock GK and Love S (2003) ApoE epsilon 4 influences the pathological phenotype of Alzheimer's disease by favouring cerebrovascular over parenchymal accumulation of a beta protein. Neuropathol Appl Neurobiol 29(3):231-281.

Chartier-Harlin MC, Parfitt M, Legrain S, Perez-Tur J, Brousseau T, Evans A, Berr C, Vidal O, Roques P, Gourlet V (1994) Apolipoprotein E, epsilon 4 allele as a major risk factor for sporadic early and late-onset forms of Alzheimer's disease: Analysis of the 19q13.2 chromosomal region. Hum Mol Genet 3(4):569-574.

Corder EH, Saunders AM, Strittmatter WJ, Schmechel DE, Gaskell PC, Small GW, Roses AD, Haines JL and Pericak-Vance MA (1993) Gene dose of apolipoprotein E type 4 allele and the risk of Alzheimer's disease in late onset families. Science 261:921-923.

Egensperger R, Kosel S, Schnabel R, Mehraein P and Graeber MB (1995) Apolipoprotein E genotype and neuropathological phenotype in two members of a German family with chromosome 14-linked early onset Alzheimer's disease. Acta Neuropathol 90:257-265.

Eto M, Saito M, Okada M, Kume Y, Kawasaki F, Matsuda M, Yoneda M, Matsuki M, Takigami S and Kaku K (2002) Apolipoprotein E genetic polymorphism, remnant lipoproteins, and nephropathy in type 2 diabetic patients. Am J Kidney Dis 40(2):243-251.

Farrer LA, Cupples LA, Haines JL, Hyman B, Kukull WA, Mayeux R, Myers RH, Pericak-Vance MA, Risch N and van Duijn CM (1997) Effect of age, sex and ethnicity on the association between apolipoprotein E genotype and Alzheimer's disease. A meta-analysis. ApoE and Alzheimer's disease, Meta-Analysis Consortium. JAMA 278(16):13491356.

Gostynski M, Ajdacic-Gross V, Gutzwiller F, Michel JP and Herrmann F (2002) Prevalence of dementia in the City of Zurich. Soz Praventivmed 47(5):330-335.

Hardy J (1995) Apolipoprotein E in the genetics and epidemiology of Alzheimer's disease. Am J Med Genet 60:456-460.

Hawi Z, Sheehan K, Lynch A, Evans I, Lowe N, Lawlor B and Gill M (2003) Late onset Alzheimer's disease and apolipoprotein association in the Irish population: Relative risk and attributable fraction. Ir J Med Sci 172(2):74-76.

Houlden H, Collinge J, Kennedy A, Newman S, Rossor M, Lannfelt L, Lilius L, Winblad B, Crook R, Duff K and Hardy J (1993) ApoE genotype and Alzheimer's disease. Lancet 342:737-738.

Houlden H, Crook R, Hardy J, Roques P, Collinge J and Rossor M (1994) Confirmation that familial clustering and age of onset in late onset Alzheimer's disease are determined at the apolipoprotein E locus. Neurosci Lett 174:222-224.

Hu CJ, Sung SM, Liu HC, Hsu WC, Lee LS, Lee CC, Tsai CH and Chang JG. (2002) Genetic risk factors of sporadic Alzheimer's disease among Chinese in Taiwan. J Neurol Sci 181:127-131.

Itoh Y and Yamada M (1996) Apolipoprotein E and the neuropathology of dementia. New England J Med 334(9):599600.

Kalina A, Szalai C, Prohaszka Z, Reiber I and Csaszar A (2002) Association of plasma lipid levels with apolipoprotein E polymorphism in Type 2 diabetes. Diabetes Res Clin Pract 56(1):63-68.

Lahoz C, Schaefer EJ, Cupples LA, Wilson PW, Levy D, Osgood D, Parpos S, Pedro-Botet J, Daly JA and Ordovas JM (2001) 
Apolipoprotein E genotype and cardiovascular disease in the Framingham Heart Study. Atherosclerosis 154(3):529-537.

Lambert JC, Perez-Tur J, Dupire MJ Galasko D, Mann D, Amouyel P, Hardy J, Delacourte A and Chartier-Harlin MC (1997) Distortion of allelic expression of apolipoprotein E in Alzheimer's disease Hum Mol Genet 6:2151-2154.

Laws SM, Clarnette RM, Taddei K, Martins G, Paton A, Hallmayer J, Almeida OP, Groth DM, Gandy SE, Forstl H and Martins RN (2002) ApoE-epsilon4 and apoE -491A polymorphism in individuals with subjective memory loss. Mol Psychiatry 7(7):768-775.

Lippa CP, Smith TW, Saunders AM Crook R, Pulaski-Salo D, Davies P, Hardy J, Roses AD and Dickson D (1995) Apolipoprotein E genotype and Lewy body disease. Neurology 45:97-103.

Nielsen AS, Ravid R, Kamphorst W and Jorgensen OS (2003) Apolipoprotein E epsilon 4 in an autopsy series of various dementing disorders. J Alzheimers Dis 5(2):119-125.

Saunders AM, Strittmatter WJ, Schmechel D, St George-Hyslop PH, Pericak-Vance MA, Joo SH, Rosi BL, Gusella JF, Crapper-McLachlan DR, Alberts MJ, Hulette C, Crain B, Goldgaber D and Roses AD (1993) Association of apolipoprotein E allele epsilon 4 with late-onset familial and sporadic Alzheimer's disease. Neurology 43:1467-1472.
Schmechel DE, Saunders AM, Strittmatter WJ, Crain BJ, Hulette CM, Joo SH, Pericak-Vance MA, Goldgaber D and Roses AD (1993) Increased amyloid beta-peptide deposition in cerebral cortex as a consequence of apolipoprotein E genotype in late-onset Alzheimer disease. Proc Nat Acad Sci USA 90:9649-9653.

Strittmatter WJ, Saunders AM, Schmechel D, Pericak-Vance M, Enghild J, Salvesen GS and Roses AD (1993) Apolipoprotein E: High avidity binding to beta-amyloid and increased frequency of type 4 allele in late onset familial Alzheimer's disease. Proc Natl Acad Sci USA 90(5):19771981

van Duijn CM, de Knijff P, Wehnert A, De Voecht J, Bronzova JB, Havekes LM, Hofman A and Van Broeckhoven C (1995). Reduced survival of patients with early-onset Alzheimer's disease that carry the Apolipoprotein E2 allele. Ann Neurol 37:605-610.

Wozniak MA, Itzhaki RF, Faragher EB, James MW, Ryder SD, Irving WL and Trent HCV Study Group (2002) Apolipoprotein E-epsilon 4 protects against severe liver diseases caused by hepatitis C virus. Hepatology 36(2):456-463.

Yip AG, Brayne C, Easton D and Rubinsztein DC (2002) Apolipoprotein E4 is only a weak predictor of dementia and cognitive decline in the general population. J Med Genet 39(9):639-643.

Associate Editor: Mayana Zatz 